\title{
PENGARUH SOCIAL MEDIA MARKETING, STORE ENVIRONMENT, SALES PROMOTION, DAN PERCEIVED VALUE TERHADAP PURCHASE DECISION KONSUMEN SOGO DEPARTMENT STORE
}

\author{
Priandy Yaputra \\ Program Studi Magister Manajemen Universitas Tarumanagara \\ priandyy93@gmail.com
}

\begin{abstract}
This research was conducted to determine the effect of social media marketing, store environment, sales promotion, and perceived value to purchase decision SOGO Department Store. This research uses a quantitative method that is by distributing questionnaires to 100 respondents who have bought goods at SOGO in West Jakarta. The research method in this study used multiple regression analysis assisted by SPSS. The results of this study are known that simultaneously all independent variables have an influence on purchase decision. Partially, the variables of the store environment, sales promotion, and perceived value have a significant influence on consumer purchase decision, while the social media marketing variable do not significantly influence consumer purchase decision.
\end{abstract}

Abstrak : Penelitian ini dilakukan untuk mengetahui pengaruh pemasaran sosial media, kondisi lingkungan toko, promosi penjualan, dan persepsi nilai terhadap keputusan membeli SOGO Department Store. Penelitian ini menggunakan metode kuantitatif yaitu dengan menyebar kuesioner kepada 100 responden yang pernah membeli barang di SOGO wilayah Jakarta Barat. Metode penelitian pada penelitian ini menggunakan analisis regresi berganda yang dibantu dengan SPSS. Hasil dari penelitian ini diketahui bahwa secara simultan semua variabel bebas memiliki pengaruh terhadap keputusan membeli konsumen. Secara parsial, variabel kondisi lingkungan toko, promosi penjualan, dan nilai keuntungan memberikan pengaruh yang signifikan terhadap keputusan membeli konsumen, sedangkan variabel pemasaran sosial media tidak berpengaruh secara signifikan terhadap keputusan membeli konsumen.

Keywords : Social Media Marketing, Store Environment, Sales Promotion, Perceived Value, Purchase Decision

\section{Pendahuluan}

Salah satu bisnis yang mengalami perkembangan pesat dari tahun ke tahun adalah bisnis retail. Tingginya tingkat konsumsi masyarakat Jakarta memicu pengusaha untuk mengembangkan bisnisnya di bidang retail. Bervariasinya retail yang ada menyebabkan timbulnya wadah yang menggabungkan beberapa usaha retail yang menawarkan sejumlah barang yang sejenis ataupun berbeda dalam volume besar yang disebut dengan Department Store.

Dalam Idntimes.com tanggal 27 Oktober tahun 2017, disebutkan bahwa ada beberapa Department Store yang menutup gerainya pada tahun 2017 seperti Matahari, Lotus, dan Debenhams. Salah satu alasan terjadinya penutupan itu menurut Ridwan selaku Ketua Umum Asosiasi Pengelola Pusat Belanja Indonesia (APPBI) adalah "terjadinya perubahan perilaku konsumen yang cenderung langsung membeli barang yang diinginkan dan pulang." Perilaku konsumen sangat berhubungan dan berkaitan erat dengan keputusan konsumen dalam membeli barang.

Dalam penelitian Hutter et al (2017) mengenai pengaruh social media terhadap keputusan membeli menemukan bahwa social media marketing menjadi faktor penting yang mempengaruhi keputusan membeli konsumen karena tingginya pengguna sosial media saat ini. 
Penelitian lain (Villiers, Chinomona, dan Chuchu, 2017) juga mengatakan bahwa pentingnya membangun lingkungan toko yang menarik merupakan faktor yang sangat penting dan berpengaruh terhadap keputusan membeli konsumen karena menciptakan suasana toko yang menyenangkan dan unik adalah faktor yang sangat penting.

Menurut Hanaysha (2016), menambahkan nilai-nilai tertentu (perceived value) merupakan hal yang penting dalam membangun kesetiaan dan kepuasan konsumen. Dalam penelitian lain (Zoellner dan Schaefers, 2015) juga disebutkan bahwa promosi penjualan mengenai harga jual merupakan salah satu strategi yang paling sering digunakan oleh manager marketing untuk meningkatkan penjualan. Maka dari itu, penelitian ini dilakukan untuk mengetahui pengaruh social media marketing, store environment, sales promotion, dan perceived value, terhadap keputusan membeli SOGO Department Store di Jakarta Barat.

\section{Tujuan Penelitian}

Tujuan dilakukannya penelitian ini adalah:

1. Untuk mengetahui pengaruh social media marketing terhadap purchase decision SOGO Department Store.

2. Untuk mengetahui pengaruh store environment terhadap purchase decision SOGO Department Store.

3. Untuk mengetahui pengaruh sales promotion terhadap purchase decision SOGO Department Store.

4. Untuk mengetahui pengaruh perceived value terhadap purchase decision SOGO Department Store.

\section{Tinjauan Pustaka}

\section{Ritel dan Department Store}

Perdagangan ritel menurut Ma'ruf(2005) adalah kegiatan usaha menjual barang atau jasa kepada konsumen perorangan untuk keperluan sendiri, keluarga, atau rumah tangga. Menurut Levy et al (2001) retailing merupakan satu rangkaian aktivitas bisnis untuk menambah nilai guna barang dan jasa yang dijual kepada konsumen untuk konsumsi pribadi atau rumah tangga. Menurut Berman dan Evans (2001) retailing merupakan suatu usaha bisnis yang berusaha memasarkan barang dan jasa kepada konsumen akhir yang menggunakannya untuk keperluan pribadi dan rumah tangga.

\section{Purchase Decision}

Menurut Setiadi (2008), keputusan pembelian merupakan perilaku konsumen dalam memperlakukan pengambilan keputusan konsumen sebagai pemecahan masalah yang dihadapinya. Menurut Kotler dan Keller (2016) keputusan pembelian merupakan proses psikologi dasar yang memainkan peran penting dalam memahami bagaimana konsumen secara aktual mengambil keputusan pembelian. Menurut Ma'ruf (2005) proses keputusan konsumen bukanlah berakhir dengan pembelian, namun berlanjut hingga pembelian tersebut menjadi pengalaman bagi konsumen dalam menggunakan produk yang dibeli tersebut.

\section{Social Media Marketing}

Menurut Kotler dan Keller (2016) media sosial adalah media yang digunakan oleh konsumen untuk berbagi teks, gambar, suara, dan video yang sebelumnya tidak tersedia bagi orang awam. Menurut Kerpen (2011) media sosial adalah teks, gambar, video, dan kaitan secara daring yang dibagikan diantara orang-orang dan pribadi. Menurut Valenza et al (2014) media sosial adalah platform internet yang memungkinkan bagi individu untuk berbagi secara cepat dan berkomunikasi secara terus menerus dengan komunitasnya. 


\section{Store Environment}

Menurut Dunne dan Lusch (2005) Store Environment merupakan unsur penting dalam retailling mengingat bahwa $70 \%$ dari pembelian ternyata merupakan permbelian yang tidak direncanakan. Menurut Kotler dan Keller (2016), Lingkungan toko juga dapat mempengaruhi pembelian dalam toko tersebut, didukung melaui teori, bahwa store atmosphere yang terencana dapat menarik minat konsumen untuk membeli.

\section{Sales Promotion}

Promosi Penjualan menurut Kotler dan Keller (2016) didefinisikan sebagai kumpulan alat-alat insentif, yang sebagian besar berjangka pendek, yang dirancang untuk merangsang pembelian poduk atau jasa tertenu dengan lebih cepat dan lebih besar oleh konsumen atau pedangang. Menurut Ma'ruf (2005) promosi penjualan adalah program promosi peritel dalam rangka mendongkrak terjadinya penjualan atau untuk meningkatkan penjualan atau dalam rangka mempertahankan minat pelanggan untuk tetap berbelanja padanya.

\section{Perceived Value}

Customer perceived value adalah trade off antara manfaat yang dipersepsikan dan pengorbanan yang dipersepsikan (Payne dan Holt, 2001). Manfaat yang dipersepsikan merupakan kombinasi dari sejumlah elemen, yaitu : atribut fisik, atribut pelayanan dan dukungan teknik yang diperoleh dalam menggunakan produk. Sedangkan pengorbanan yang dipersepsikan terdiri dari seluruh biaya pembelian yang terjadi pada saat membeli; misalkan harga pembelian, biaya akuisisi, transportasi, instalasi, biaya penanganan, perbaikan dan pemeliharaan, dan resiko kegagalan atau kinerja yang buruk. Perceived value adalah penilaian konsumen secara keseluruhan terhadap manfaat produk yang didasarkan dari apa yang mereka terima dan apa yang mereka berikan (Lai, 2004).

Berdasarkan pemaparan di atas, hipotesis yang diajukan dalam penelitian ini adalah sebagai berikut:

$\mathrm{H}_{1}$ : Social media marketing berpengaruh secara signifikan terhadap purchase decision.

$\mathrm{H}_{2}$ : Store environment berpengaruh secara signifikan terhadap purchase decision.

$\mathrm{H}_{3}$ : Sales promotion berpengaruh secara signifikan terhadap purchase decision.

$\mathrm{H}_{4}$ : Perceived value berpengaruh secara signifikan terhadap purchase decision.

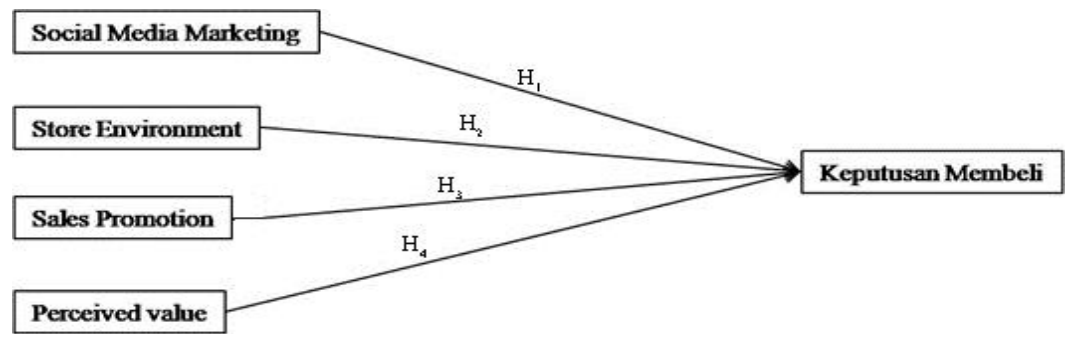

Gambar 1.1 Kerangka Pemikiran Penelitian

\section{Metode Penelitian}

Subjek pada penelitian ini adalah SOGO Department Store. Pemilihan subjek penelitian ini dengan pertimbangan bahwa SOGO Department Store ini merupakan Department Store yang memliki pertumbuhan stabil dari tahun ke tahun khususnya di Jakarta.

Pengambilan sampling pada penelitian ini menggunakan teknik purposive sampling, yaitu teknik untuk menentukan sampel penelitian dengan beberapa pertimbangan tertentu yang bertujuan agar data yang diperoleh nantinya bisa lebih representatif (Sugiyono, 2012). Sehingga sampel yang dipilih adalah konsumen-konsumen yang pernah membeli barang di SOGO Department Store Jakarta Barat. Menurut Hair et al (2010) jumlah sampel yang 
digunakan dalam suatu penelitian adalah minimal 5 kali dari jumlah indikator pada semua variabel dimana jumlah sampel yang disarankan minimal 100 responden atau lebih. Pada penelitian ini menggunakan 20 indikator penelitian, maka dari itu jumlah sampel yang diambil adalah $5 \times 20=100$ responden. Penelitian ini menggunakan analisis regresi berganda dengan tujuan untuk mengetahui pengaruh antara variabel independen terhadap variabel dependen.

\section{Hasil \& Kesimpulan}

Tabel 1.1 Hasil Uji F (Anova) Regresi Berganda

\begin{tabular}{|c|c|c|c|c|c|c|}
\hline \multicolumn{2}{|c|}{ Model } & $\begin{array}{l}\text { Sum of } \\
\text { Squares }\end{array}$ & $\mathrm{df}$ & Mean Square & $\mathrm{F}$ & Sig. \\
\hline \multirow[t]{3}{*}{1} & Regression & 241.783 & 4 & 60.446 & 16.222 & $.000^{\mathrm{a}}$ \\
\hline & Residual & 353.977 & 95 & 3.726 & & \\
\hline & Total & 595.760 & 99 & & & \\
\hline
\end{tabular}

Berdasarkan tabel diatas dapat dilihat bahwa nilai $\mathrm{F}$ hitung pada tabel hasil pengolahan dengan menggunakan program SPSS adalah 16,222. Nilai $F$ tabel dengan tingkat keyakinan $(\alpha)=0,05$ adalah 2,4625 sehingga $F$ hitung $16,222>F$ tabel 2,4625. Selain itu, jika dilihat dari nilai sig pada tabel diatas adalah $0,000<0,05$. Hal ini berarti bahwa variabel independen social media marketing, store environment, sales promotion, dan perceived value secara simultan mempengaruhi secara signifikan terhadap purchase decision.

Tabel 1.2 Hasil Uji t Regresi Berganda

\begin{tabular}{|l|r|r|r|r|r|}
\hline \multirow{2}{*}{ Model } & \multicolumn{2}{|c|}{$\begin{array}{c}\text { Unstandardized } \\
\text { Coefficients }\end{array}$} & $\begin{array}{c}\text { Standardized } \\
\text { Coefficients }\end{array}$ & \multicolumn{1}{c|}{} \\
\cline { 2 - 5 } & \multicolumn{1}{|c|}{$\mathrm{B}$} & Std. Error & \multicolumn{1}{c|}{ Beta } & \multicolumn{1}{c|}{ S } & \multicolumn{1}{c|}{ Sig. } \\
\hline $1 \quad$ (Constant) & 3.843 & 1.693 & & 2.269 & .026 \\
SocialMedia & .077 & .107 & .058 & .725 & .470 \\
StoreEnvironment & .221 & .099 & .223 & 2.226 & .028 \\
SalesPromotion & .292 & .106 & .240 & 2.757 & .007 \\
PerceivedValue & .392 & .106 & .349 & 3.689 & .000 \\
\hline
\end{tabular}

Berdasarkan tabel hasil analisis regresi berganda diatas, dapat dilihat bahwa variabel independen social media marketing memiliki sig 0,470>0,05 yang berarti social media marketing tidak berpengaruh secara signifikan terhadap purchase decision. Sementara variabel independen store environment, sales promotion, dan perceived value memiliki sig lebih kecil dari 0,05 sehingga secara parsial variabel independen store environment, sales promotion, dan perceived value berpengaruh signifikan terhadap purchase decision.

Berdasarkan hasil penelitian, maka kesimpulan dari penelitian ini adalah sebagai berikut:

1. Social media marketing memberikan pengaruh yang tidak signifikan terhadap purchase decision konsumen SOGO Department Store.

2. Store environment memberikan pengaruh yang signifikan terhadap purchase decision konsumen SOGO Department Store.

3. Sales promotion memberikan pengaruh yang signifkan terhadap purchase decision konsumen SOGO Department Store.

4. Perceived value memberikan pengaruh yang signifikan terhadap purchase decision konsumen SOGO Department Store. 
Berdasarkan hasil dari penelitian ini, maka ada beberapa saran yang dapat diberikan oleh peneliti, yaitu sebagai berikut:

1. Saran bagi Praktisi

Indikator variabel penelitian yang memiliki nilai rata-rata paling tinggi adalah SOGO Department Store selalu terlihat bersih dengan rata-rata 4,10. Hal ini berarti bahwa pihak manajemen SOGO Department Store harus tetap mempertahankan dan selalu memperhatikan kebersihan di setiap tokonya. Indikator variabel penelitian yang memiliki nilai rata-rata paling rendah adalah iklan di sosial media mudah diingat dengan nilai rata-rata 2,27. Hal ini berarti bahwa pihak manajemen SOGO Department Store tidak perlu terlalu fokus pada kegiatan di sosial media karena selain sosial media memiliki nilai rata-rata yang rendah, variabel penelitian social media marketing juga tidak berpengaruh secara signifikan terhadap keputusan membeli konsumen.

\section{Saran bagi Akademisi}

Penelitian ini hanya menggunakan empat variabel bebas yaitu social media marketing, store environment, sales promotion, dan perceived value untuk mengukur pengaruh purchase decision konsumen SOGO Department Store. Masih ada faktorfaktor lainnya yang berpotensi untuk mempengaruhi purchase decision konsumen SOGO Department Store yang dapat diteliti lebih lanjut seperti faktor personal, faktor sosial, dan faktor psikologi seperti yang dikemukakan oleh Khuong dan Hoang (2016), Suroto et al (2013). Selain menggunakan variabel lain, peneliti selanjutnya juga disarankan untuk menambah responden, cakupan wilayah, dan profil demografinya.

\section{Daftar Pustaka}

Berman, B., \& Evans, Joel R. (2001). Retail Management: A Strategic Approach. Prentice Hall. Dunne, Patrick M., \& Lusch, Robert F. (2005). Retailing. Thomson : South-Western.

Hair et al. (2010). Multivariate Data Analysis, Seventh Edition. Pearson Prentice Hall.

Hanaysha, J.R. (2016), "The importance of social media advertisements in enhancing brand equity: a study on fast food restaurant industry in Malaysia", Business and Economic Research. 6(1), pp.46-51.

Hanaysha, J.R. (2017). “An examination of the factors affecting consumer's purchase decision in the Malaysian retail market". PSU Research Review. 2. pp.7-23.

Hutter et al. (2013)."The impact of user interactions in social media on brand awareness and purchase intention: the case of MINI on Facebook", Journal of Product \& Brand Management, Vol. 22 Issue: 5/6, pp.342-351.

Kerpen, Dave. (2011). Likeable Social Media: How to Delight Your Customers, Create an Irresistible Brand, and Be Generally Amazing on Facebook (\&Other Social Networks), McGraw Hill Professional.

Khuong, Mai N. \& Hoang D.T.M. (2016). "Personal Factors Affecting Consumer Purchase Decision towards Men Skin Care Products". International Journal of Trade, Economics and Finance, 7(2). pp.44-50.

Kotler, Philip \& Keller, Kevin Lane. (2016). Marketing Management 15th Edition. Pearson Education, Inc.

Lai, Tung. (2004). "Service quality and perceived value's impact on satisfaction, intention and usage of short message service". Information Systems Frontiers. 6. pp.353-368.

Levy, Michael., Barton A., Weitz. (2001). Retailing Management. Irwin : McGraw-Hill.

Ma'ruf, Hendri. (2005). Pemasaran Ritel. Jakarta : Gramedia.

Payne, A., dan Holt, S. (2001). "Diagnosing customer value: integrating the value process and relationship marketing". British Journal of Management. 12. pp.159-182.

Setiadi, Nugroho J. (2008), Perilaku Konsumen, Jakarta : PT Kencana.

Sugiyono. (2012). Metode Penelitian Kuantitatif Kualitatif dan R\&D. Bandung: Alfabeta. 
Suroto et al. (2013). "Factors influencing consumer's purchase decision of formula milk in Malang City". Journal of Business and Management. 9(3) pp.95-99.

Valenza, Joyce K., Brenda L., Della C., (2014). Social Media Curation. American Library Association.

Villiers, Marike, Richard, C. dan Tinashe, C.(2017)." The influence of store environment on brand attitude, brand experience and purchase intention" South African Journal of Business Management. 49(1). pp186.

Zoellner, F. dan Schaefers, T. (2015), " The impact of price promotion types on sales and brand perception of premium products", Developments in Marketing Science: Proceedings of the Academy of Marketing Science in Ideas in Marketing: Finding the New and Polishing the Old, Springer, Cham, pp.528. 